\title{
HEPATOPROTECTIVE EFFECT OF BELLAMYA JAVANICA: ASPARTATE TRANSAMINASE, ALANINE AMINOTRANSFERASE, AND ALKALINE PHOSPHATASE ACTIVITY, AND LIVER HISTOPATHOLOGY IN MICE INDUCED WITH CARBON TETRACHLORIDE
}

\author{
FADLINA CHANY SAPUTRI ${ }^{1 *}$, CAROLINA ASTARI ${ }^{1}$, DYAH ADINDA JANATRY ${ }^{1}$, AZIZAHWATI ${ }^{1}$, DADANG KUSMANA ${ }^{2}$ \\ ${ }^{1}$ Departmentof Pharmacology, Faculty of Pharmacy, Universitas Indonesia, Depok 16424, Indonesia. ${ }^{2}$ Department ofBiology, Faculty of
} Mathematics and Natural Sciences, Universitas Indonesia, Depok 16424, Indonesia. Email: fadlina.chany@farmasi.ui.ac.id

Received: 10 April 2018, Revised: 28 September 2018, Accepted: 25 November 2018

\section{ABSTRACT}

Objective: The aim of this study was to evaluate the hepatoprotective effects of Bellamya javanica meat (BJM) in mice by quantifying alanine aminotransferase (ALT), aspartate transaminase (AST), and alkaline phosphatase (ALP) activity and observing liver histology.

Methods: A total of 36 white male Sprague-Dawley mice were divided into six groups, namely a normal control group, a negative control group (0.5\% carboxymethyl cellulose), a positive control group (silymarin with a dosage of $9.45 \mathrm{mg} / 200 \mathrm{~g}$ mouse weight), dosage $1 \mathrm{group}$ (BJM powder at $1 \mathrm{~g} / \mathrm{kg}$ mouse weight), dosage 2 group (BJM powder at $2 \mathrm{~g} / \mathrm{kg}$ mouse weight), and dosage 3 group (BJM powder at $4 \mathrm{~g} / \mathrm{kg}$ mouse weight). Mice were treated for 14 days. On the $15^{\text {th }}$ day, all groups (except the normal control group) were induced with carbon tetrachloride and fed $a d$ libitum. After $24 \mathrm{~h}$ of induction, ALT, AST, and ALP in serum were quantified, and livers were dissected for histopathological examination.

Results: The results showed that the consumption of BJM at doses of 2 and $4 \mathrm{~g} / \mathrm{kg}$ mouse weight cast a hepatoprotective effect compared with the negative control group. In addition, there were significant differences in the hepatoprotective effect between the various doses of BJM. The dosage with the highest potential hepatoprotective effect was $4 \mathrm{~g} / \mathrm{kg}$ mouse weight $(\mathrm{p}<0.05)$.

Conclusion: B. javanica has potential hepatoprotective effects, with the strongest protection occurring at a $4 \mathrm{~g} / \mathrm{kg}$ mouse weight dosage. Hepatoprotection was observed in the form of decreased AST, ALT, and ALP activity and relevant changes in liver histopathology.

Keywords: Alanine aminotransferase, Alkaline phosphatase, Aspartate transaminase, Bellamya javanica, Liver histology.

(C) 2018 The Authors. Published by Innovare Academic Sciences Pvt Ltd. This is an open access article under the CC BY license (http://creativecommons. org/licenses/by/4. 0/) DOI: http://dx.doi.org/10.22159/ijap.2018.v10s1.45

\section{INTRODUCTION}

The liver is highly susceptible to damage next to the digestive system due to its exposure to toxins. Liver damage is primarily caused by exogenous compounds, such as certain drugs and pollutants, present in toxic chemicals. Examples of compounds that can elicit liver damage include paracetamol (acetaminophen), carbon tetrachloride $\left(\mathrm{CCl}_{4}\right)$, thioacetamide, and alcohol (ethanol) [1-3].

Liver damage typically results in cellular necrosis, increased lipid peroxidation, and decreased glutathione (GSH) levels. In addition, the serum activity of various biochemical markers, including aspartate transaminase (AST), alanine aminotransferase (ALT), triglycerides, and alkaline phosphatase (ALP), also increases [4].

Bellamya javanica, a gastropod abundant in Indonesia, is a natural ingredient, believed by civilians, to be effective in maintaining liver health $[5,6]$. It is consumed as part of regular meal to help prevent liver disease. The consumption of $B$. javanica meat (BJM) is believed by the traditional community to strengthen bones and to treat ailments, such as gastritis, arthritis, and various liver disorders [7].

Although the specific contents of $B$. javanica have not been identified, the related gastropod Bellamya bengalensis has been shown to possess a high protein content [8]. In addition, B. bengalensis has been shown to cast hepatoprotective effects as it has the ability to significantly decrease the activity of important liver biochemical markers (AST, ALT, and ALP) in male Wistar mice induced with $\mathrm{CCl}_{4}$ [7]. Therefore, the related $B$. javanica may also cast hepatoprotective effects thanks to its proteins that play an important role in the biosynthesis of GSH, a critical antioxidant that protects against the free radicals that may cause liver damage [9].

\section{MATERIALS AND METHODS}

Materials

B. javanica was gathered from paddy fields in Cianjur and was further analyzed at the Indonesian Scientific Research and Development Center or the Pusat Penelitian dan Pengembangan Lembaga Ilmu Pengetahuan Indonesia located in Bogor (No. 050a/IIPI.1.02/K5.02/II/2015). The conventional hepatoprotective agent used as a positive control in this study was silymarin (Nature's Bounty, New York). Hepatotoxic induction was conducted with $\mathrm{CCl}_{4}$ (Merck, USA and Canada) diluted in coconut oil (Barco, Indonesia) at a 1:1 ratio.

\section{Test material preparation}

Fresh $B$. javanica was washed with running water and boiled at low heat, and the meat was extracted from its shell. The operculum was then separated from the meat and weighed. The BJM was pureed with aquadest using a blender and then placed in a freeze-dryer bottle and frozen for $24 \mathrm{~h}$. After the samples were frozen, the bottles containing the frozen BJM were placed in a freeze-dryer machine (Scanvac Coolsafe, Denmark) for several days until the meat become consistent with powder, which was then smoothed again [10]. The B. javanica dried meat powder was then suspended in $0.5 \%$ carboxymethyl cellulose (CMC) at dosages of 1,2 , and $4 \mathrm{~g} / \mathrm{kg}$ mouse weight to be administered orally.

\section{Qualitative test}

Qualitative tests on the BJM powder were performed to identify its protein content. The Biuret test, Xanthoproteic test, Millon's test, and lead acetate test were conducted. The results from these tests confirmed that the BJM contained protein. 


\section{Animal testing}

The animals used in this study included 42 white male Sprague-Dawley mice (BPOM) aged 8 weeks and weighing 150-200 g. Before being treated, mice were acclimatized for 14 days in the Animal Testing Laboratory, Faculty of Pharmacy, Universitas Indonesia (No. 255/UN2. F1/ETIK/2015). The general condition and weight of the mice were observed during the acclimatization period to select healthy mice for the study. This study passed the ethical review from the Health Research Ethics Committee, Faculty of Medicine, Universitas Indonesia.

\section{Preliminary test}

Preliminary testing was conducted to determine the dosage and the amount of days BJM powder were to be given. Preliminary testing was performed by dividing seven mice into three groups. The first group consisted of one mouse as a control group, while the second and third groups consisted of two mice each, one as a control and one to be given treatment (Table 1)

After the last BJM suspension was given, mice were left alone for $24 \mathrm{~h}$ and then induced with $\mathrm{CCL}_{4}$ diluted in coconut oil (1:1) at a dosage of $1 \mathrm{~mL} / \mathrm{kg}$ mouse weight [11-13]. After the mice were induced, they were fed ad libitum for $24 \mathrm{~h}$. After $48 \mathrm{~h}$, mice were anesthetized with ether, and blood from the orbital sinus was extracted and measured for its plasma ALT and AST levels.

\section{Hepatoprotective activity test}

Pre-treatment animal testing

Pre-treatment experiments were performed in which the test animals were given silymarin and BJM according to each group dosage for 14 days. The animals were randomly divided into six groups as described in Table 2.

\section{Hepatotoxic induction}

After 14 days of pretreatment, test animals were induced for $24 \mathrm{~h}$ after the last treatment was given to all treatment groups, excluding the normal control group. After they were induced with $\mathrm{CCl}_{4}$, the mice were fed ad libitum for $24 \mathrm{~h}$. The test animals were then anesthetized with ether, and blood samples were taken from the orbital sinus. Livers were also extracted for histopathological analysis.

\section{Blood withdrawal}

Blood was withdrawn from the orbital sinus and collected in $\mathrm{K}_{2}$ ethylenediaminetetraacetic acid Vacutainer to prevent coagulation.

Table 1: Treatment given to the mice in the preliminary test

\begin{tabular}{|c|c|c|c|}
\hline \multirow[t]{2}{*}{ Groups } & \multicolumn{3}{|c|}{ Duration of treatment } \\
\hline & 1 week & 2 weeks & 3 weeks \\
\hline Normal control & \multirow{3}{*}{\multicolumn{3}{|c|}{$\begin{array}{l}\text { Given CMC } 0.5 \% 3 \mathrm{~mL} / 200 \mathrm{~g} \text { mouse weight } \\
\text { Given CMC } 0.5 \% 3 \mathrm{~mL} / 200 \mathrm{~g} \text { mouse weight } \\
\text { Given BJM suspension } 2 \mathrm{~g} / \mathrm{kg} \text { bb mouse }\end{array}$}} \\
\hline Negative control & & & \\
\hline Treatment & & & \\
\hline
\end{tabular}

BJM: Bellamya javanica meat. CMC: Carboxymethyl cellulose
Samples were then centrifuged at a speed of $3000 \mathrm{rpm}$ for $5 \mathrm{~min}$ to extract the plasma, and a plain vacutainer was left to be separated at room temperature followed by centrifugation at $3000 \mathrm{rpm}$ for $15 \mathrm{~min}$ to extract the serum.

\section{AST, ALT, and ALP quantification}

The selection of kinetic methods used to quantify AST and ALT activity was based on recommendations from the IFCC (International Federation of Clinical Chemistry) Expert Panel, without pyridoxal phosphate activation. AST and ALT activity quantification was performed at a wavelength of $340 \mathrm{~nm}$ and a temperature of $25^{\circ} \mathrm{C}$. Serum ALP activity was quantified using a colorimetry kit (Human, Germany).

\section{Histopathology}

Isolated livers were placed inside a beaker containing $0.9 \mathrm{M} \mathrm{NaCl}$. The fixation solution used in this study was the Bouin solution, which consists of $5 \%$ saturated picric acid $(75 \mathrm{~mL}), 40 \%$ formalin $(25 \mathrm{~mL})$, and glacial acetic acid $(5 \mathrm{~mL})$. Histological staining of the liver was performed using hematoxylin and eosin. Observation of the liver preparation was done semiquantitatively and quantitatively using a light microscope (Novex, Holland). The observed parameters included the diameter of the central vein and damage to the liver parenchymas, such as liver necrosis, steatosis, fibrosis, and liver cirrhosis. Semiquantitative observation was performed on 50 liver lobes from one preparation for each treatment group by determining the degree of central vein and parenchymal damage (Table 3). The quantitative observation was performed by measuring the central vein diameter using a micro projector (Ken-A-Vision, USA).

\section{Data analysis}

The obtained data included plasma AST and ALT activity, serum ALP activity, and central vein diameters and were statistically analyzed using SPSS 21.0. We used parametric tests such as the normal distribution test (Shapiro-Wilk test) and the homogeneity test (Levene's test), as well as nonparametric tests such as the Kruskal-Wallis test followed by the Mann-Whitney U-test.

\section{RESULTS}

\section{Preliminary test}

The results of the preliminary tests are shown in Table 4. These results show that in the dosage 2 treatment group, a decrease in plasma ALT and AST levels were observed; these levels approached normal levels after 14 days. A weight of $2 \mathrm{~g} / \mathrm{kg}$ was determined as the median dose of the hepatoprotective activity test.

\section{Hepatoprotective activity test}

The mean activity of AST, ALT, and ALP from each group can be seen in Table 5. All three enzymes show a decrease as the dosage of BJM increases, thus demonstrating a dose-response relationship.

The results of our analysis show that the mean diameter of the central vein was significantly different between the negative control group

Table 2: Division of animal testing groups

\begin{tabular}{|c|c|c|c|c|}
\hline No. & Group & Treatment & $24 \mathrm{~h}$ after last treatment & $\begin{array}{l}48 \mathrm{~h} \text { after last } \\
\text { treatment }\end{array}$ \\
\hline I & Normal control & $3 \mathrm{~mL} / 200 \mathrm{~g}$ weight $0.5 \% \mathrm{CMC}$ solution given orally & \multirow{6}{*}{$\begin{array}{l}1 \mathrm{~mL} / \mathrm{kg} \text { weight coconut oil } \\
\text { orally } \\
\text { Induced with } 0.5 \mathrm{~mL} / \mathrm{kg} \text { weight } \\
\mathrm{CCl}_{4} \text { in coconut oil }(1: 1) \text { orally }\end{array}$} & \multirow{6}{*}{$\begin{array}{l}\text { Blood withdrawal, } \\
\text { plasma ALP activity } \\
\text { quantification, liver } \\
\text { extraction, and heart } \\
\text { histology preparation }\end{array}$} \\
\hline II & Negative control & $3 \mathrm{~mL} / 200 \mathrm{~g}$ weight $0.5 \% \mathrm{CMC}$ solution given orally & & \\
\hline III & Positive control & $\begin{array}{l}\text { Silymarin suspended in } 0.5 \% \text { CMC } 9.45 \mathrm{mg} / 200 \mathrm{~g} \text { weight } \\
\text { dose given orally }\end{array}$ & & \\
\hline IV & Dosage 1 & $\begin{array}{l}\text { BJM suspended in } 0.5 \% \mathrm{CMC} \text { with } 1 \mathrm{~g} / \mathrm{kg} \text { weight dose given } \\
\text { orally }\end{array}$ & & \\
\hline $\mathrm{V}$ & Dosage 2 & $\begin{array}{l}\text { BJM suspended in } 0.5 \% \mathrm{CMC} \text { with } 2 \mathrm{~g} / \mathrm{kg} \text { weight dose given } \\
\text { orally }\end{array}$ & & \\
\hline VI & Dosage 3 & $\begin{array}{l}\text { BJM suspended in } 0.5 \% \text { CMC with } 4 \mathrm{~g} / \mathrm{kg} \text { weight dose given } \\
\text { orally }\end{array}$ & & \\
\hline
\end{tabular}


Table 3: Determining the level of damage in semiquantitative observations of the liver

\begin{tabular}{lll}
\hline $\begin{array}{l}\text { Level of } \\
\text { damage }\end{array}$ & Lesion (\%) & Determinate \\
\hline 1 & 0 & $\begin{array}{l}\text { Central vein and parenchymal cells are } \\
\text { not damaged }\end{array}$ \\
2 & $20-40$ & $\begin{array}{l}\text { Damage in the centrilobular area } \\
\text { Damage in the central vein and } \\
\text { parenchymal cells surrounding the } \\
\text { central vein }\end{array}$ \\
\hline
\end{tabular}

Source: Afiati (2009)

Table 4: ALT and AST activity in the preliminary test at $340 \mathrm{~nm}$ wavelength

\begin{tabular}{lllll}
\hline Measured & Group & \multicolumn{2}{l}{ Activity (UI/L) } \\
\cline { 2 - 5 } & & $\mathbf{7}$ days & 14 days & 21 days \\
\hline AST plasma & Normal control & $20.07 \pm 0.69$ & $21.17 \pm 0.54$ & $19.75 \pm 1.21$ \\
& 2 g/kg weight dose & $28.70 \pm 1.00$ & $27.57 \pm 0.59$ & $28.48 \pm 1.63$ \\
& Negative control & $60.93 \pm 0.80$ & $62.36 \pm 0.32$ & $60.85 \pm 1.50$ \\
ALT plasma & Normal control & $13.47 \pm 0.35$ & $14.92 \pm 0.26$ & $15.23 \pm 0.32$ \\
& 2 g/kg weight dose & $19.88 \pm 1.12$ & $18.59 \pm 0.34$ & $19.11 \pm 0.69$ \\
& Negative control & $39.69 \pm 0.48$ & $40.36 \pm 0.77$ & $43.69 \pm 0.86$ \\
\hline Activity scores in mean $\pm S D$. AST: Aminotransferase, ALT: Aspartate \\
transaminase. SD: Standard deviation
\end{tabular}

Table 5: Results of AST, ALT, and ALP activity (U/l)

\begin{tabular}{llll}
\hline \multirow{2}{*}{ Group } & \multicolumn{3}{l}{ Mean activity \pm SEM } \\
\cline { 2 - 4 } & AST (U/I) & ALT (U/I) & ALP (UI/L) \\
\hline Normal control & $18.06 \pm 0.92^{*}$ & $13.97 \pm 1.08^{*}$ & $117.71 \pm 5.69$ \\
Negative control & $70.09 \pm 1.68^{\#}$ & $63.55 \pm 2.69^{\#}$ & $324.67 \pm 14.36^{\#}$ \\
Positive control & $28.26 \pm 2.41^{\# *}$ & $23.57 \pm 1.75^{\# *}$ & $186.35 \pm 16.00$ \\
Dosage 1 & $65.82 \pm 2.24^{\#}$ & $57.32 \pm 3.13^{\#}$ & $321.77 \pm 13.73$ \\
Dosage 2 & $42.60 \pm 3.29^{\# *}$ & $41.70 \pm 2.66^{\# *}$ & $240.92 \pm 26.74^{*}$ \\
Dosage 3 & $37.61 \pm 3.19^{\# *}$ & $34.72 \pm 3.29^{\# *}$ & $184.03 \pm 16.06^{*}$ \\
\hline
\end{tabular}

Normal control (CMC $0.5 \%$ with a dose of $3 \mathrm{~mL} / 200 \mathrm{~g}$ weight), negative control (CMC $0.5 \%$ with a dose of $3 \mathrm{~mL} / 200 \mathrm{~g}$ weight), positive

control (silymarin $9.45 \mathrm{~g} / 200 \mathrm{~g}$ weight), dosage 1 (BJM powder $1 \mathrm{~g} / \mathrm{kg}$ weight), dosage 2 (BJM powder $2 \mathrm{~g} / \mathrm{kg}$ weight), and dosage 3 (BJM powder $1 \mathrm{~g} / \mathrm{kg}$ weight). *A significant difference was found compared with the negative control group by the Mann-Whitney U-test $(\mathrm{p}<0.05) .{ }^{* *}$ A significant difference was found compared with the normal control group by the Mann-Whitney U-test ( $\mathrm{p}<0.05)$. AST: Aminotransferase, ALT: Aspartate transaminase, ALP: Alkaline phosphatase, SEM: Standard error of the mean, BJM: Bellamya javanica meat. CMC: Carboxymethyl cellulose

and the treatment control groups of $1 \mathrm{~g} / \mathrm{kg}$ weight and $4 \mathrm{~g} / \mathrm{kg}$ weight snail meat. The dosage that produced the strongest hepatoprotective effect was $4 \mathrm{~g} / \mathrm{kg}$ weight $(\mathrm{p}<0.05)$. The dose of $1 \mathrm{~g} / \mathrm{kg}$ weight snail meat powder demonstrated a lower hepatoprotective effect compared with the negative control group ( $p>0.05)$. Similar to the ALP activity, the mean diameter of the central vein in the treatment group with $4 \mathrm{~g} / \mathrm{kg}$ weight differed from that of the normal control group $(p>0.05)$.

On the basis of the mean liver damage percentage of the normal control group, it was observed that $100 \%$ of the livers experienced only a Level 1 damage (minor damage). The mean liver damage percentage of the induced control group showed a decrease in the Level 1 damage percentage and an increase in the Level 2 damage, but no increase in Level 3 damage (Fig. 1).

A decrease in damaged hepatocyte size and the number and amount of neutrophil infiltration in the central vein were seen histologically with BJM treatment. Sinusoids fill the empty spaces between hepatocytes and spread peripherally to the central vein.

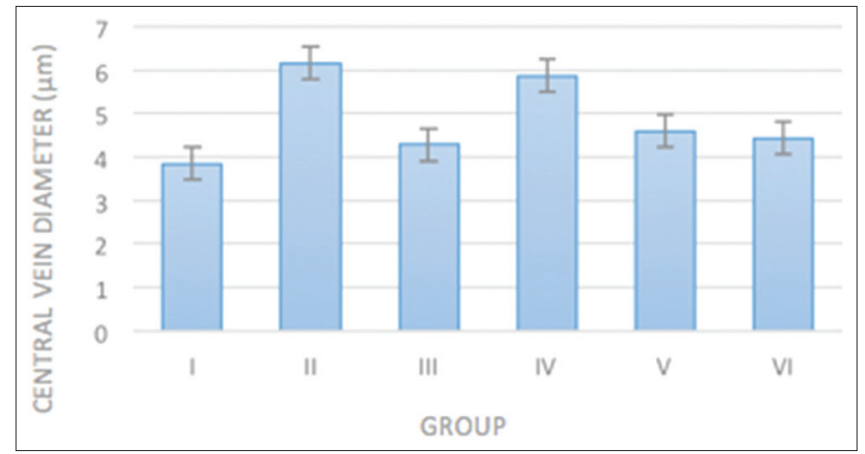

Fig. 1: Diagram of the mean central vein diameter in white male mice 14 days after treatment. Group 1, normal control (carboxymethyl cellulose [CMC] 0.5\%); Group 2, negative control (CMC 0.5\%); Group 3, positive control (silymarin $9.45 \mathrm{mg} / 200 \mathrm{~g}$ mouse weight); Group 4, Bellamya javanica meat (BJM) powder with a dose of $1 \mathrm{~g} / \mathrm{kg}$ mouse weight; Group 5, BJM powder with a dose of $2 \mathrm{~g} / \mathrm{kg}$ mouse weight; and Group 6, BJM powder with a dose of $4 \mathrm{~g} / \mathrm{kg}$ mouse weight

The histological view of the normal control group can be seen in Fig. 2a. The largest damage was seen in the negative control group, which was administered a toxic dose of $\mathrm{CCl}_{4}(1 \mathrm{~mL} / \mathrm{kg}$ weight; Figs. $2 \mathrm{~b}$ and 3 ). It shows neutrophil infiltration as a result of damage to the hepatocyte cell membrane. Microanatomical healing can be seen in the treatment group of $1 \mathrm{~g} / \mathrm{kg}$ weight dosage as described in Fig. 2c. However, this healing is much more noticeable in groups treated with BJM at $2 \mathrm{~g} / \mathrm{kg}$ weight and $4 \mathrm{~g} / \mathrm{kg}$ weight, as shown in Fig. $2 \mathrm{~d}$ and e. The dosage 1 group still shows heavy neutrophil infiltration, which is a marker of inflammation, caused by hepatocyte damage and free radicals from $\mathrm{CCl}_{4}$ metabolism [14].

Treatment groups that were given BJM at various doses showed a decrease in the damage percentage as the dose of BJM increased. The steepest decrease in liver damage was seen in the treatment group administered a BJM dose of $4 \mathrm{~g} / \mathrm{kg}$ weight that presented with Level 1 damage (66.67\%) and Level 2 damage (33.33\%). Histological analysis showed a decrease in hepatocyte size and number, as well as neutrophil infiltration in the central vein.

\section{DISCUSSION}

Qualitative tests were conducted to verify the protein content in the BJM powder using staining, including the biuret test, xanthoproteic test, Millon's test, and lead acetate test. Of the four tests, the Biuret test is a protein-specific test, while the xanthoproteic, Millon's, and lead acetate tests are amino acid-specific tests. The results of the tests were similar to those found in the studies by Chakraborty et al. (2015) toward $B$. bengalensis, a snail closely related to $B$. javanica, and showed positive results for containing proteins and amino acids [8].

$\mathrm{CCl}_{4}$ has long been recognized as a hepatotoxin, and many hepatoprotective compounds have been tested on animals to counter the effects of $\mathrm{CCl}_{4}$ [15]. $\mathrm{CCl}_{4}$ is known to be toxic toward both cells and tissues of the body, particularly to the liver and kidneys as both are sensitive to the presence of $\mathrm{CCl}_{4}$ in the body. The toxic effects of $\mathrm{CCl}_{4}$ are connected to $\mathrm{CCl}_{4}$ metabolism, which is catalyzed by the cytochrome P-450 enzyme system. In this process, trichloromethyl free radicals $\left(\mathrm{CCl}_{3}\right)$ are produced in the liver and cause lipid peroxidation, irreversible binding to macromolecules, and calcium imbalance, leading to death or degeneration of liver cells [16]. Furthermore, steatosis, fatty liver, and cholestasis may also occur [17].

AST, ALT, and ALP are markers that are sensitive to hepatocyte damage. Transaminase enzymes are highly concentrated in the liver, and an increase in enzyme activity confirms the damage in hepatocytes [15]. Damaged and acutely degenerated cells then release intracellular 


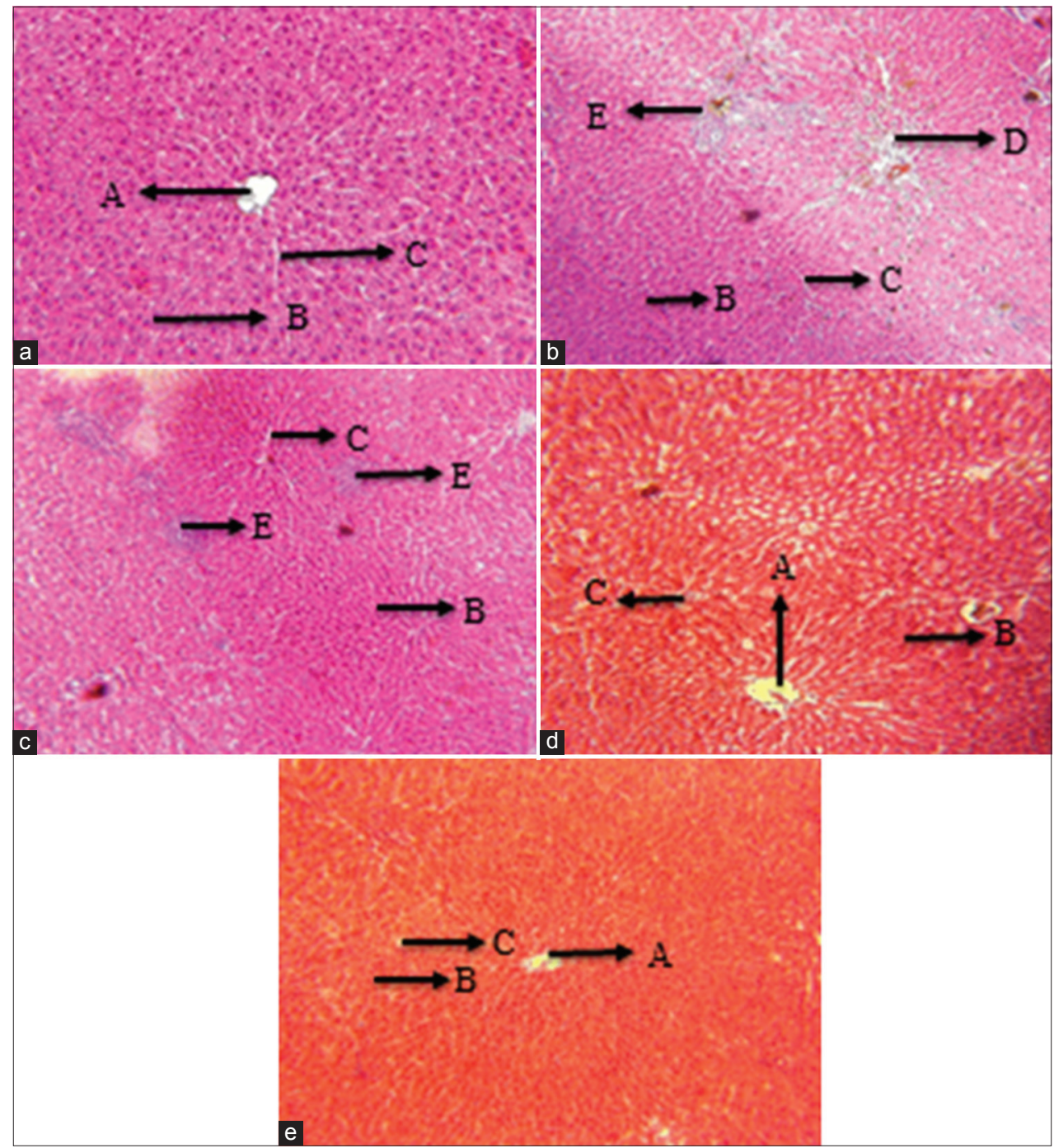

Fig. 2: Mouse liver histology for all treatment groups after 14 days of treatment (100× magnification). (a) Normal control, (b) negative control, (c) dosage 1 (1 g/kg weight), (d) dosage 2 ( $2 \mathrm{~g} / \mathrm{kg}$ weight), (e) dosage 3 (4 g/kg weight); A - central vein; B - liver cells (hepatocytes); C - sinusoid; D - hepatocyte damage (necrosis); E - neutrophil infiltration

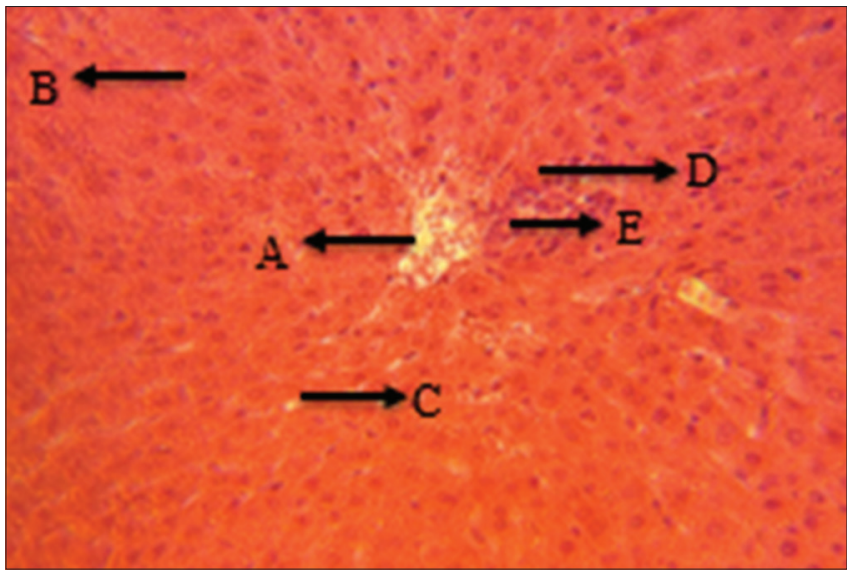

Fig. 3: Mouse liver histology of the negative control group after 14 days of treatment (400× magnification). Notes: A - central vein; B - liver cells (hepatocytes); C - sinusoid; D - hepatocyte damage (necrosis); E - neutrophil infiltration

proteins and other macromolecules into the bloodstream. Some proteins can be found only in the hepatocytes, and when they are detectable in the bloodstream, it is an additional indicator of liver damage. Some of these proteins are hepatocyte enzymes [16].

Overall, our results indicated that AST, ALT, and ALP activity decreased as the consumption of snail meat increased. This decrease likely occurred as a result of increased GSH synthesis, which is elicited by amino acids present in B. javanica, such as glutamine, cysteine, and glycine. This increase promotes a body defense toward oxidative stress caused by reactive oxygen species and $\mathrm{CCl}_{3}$ from $\mathrm{CCl}_{4}$ metabolism in hepatocytes $[2,18,19]$. GSH activity as an antioxidant is a result of the presence of the Sulfhydryl (SH) chain, which is highly nucleophilic and very reactive toward electrophilic free radicals, conferring good affinity toward the free radicals produced from $\mathrm{CCl}_{4}[19,20]$.

Our results of AST, ALT, and ALP activity measurements were supported by histological examinations of the liver. Administering $\mathrm{CCl}_{4}$ caused damage to the liver lobes, including hepatocyte necrosis and neutrophil infiltration of the central vein and hepatocytes, indicating an increase in inflammatory processes in the area. Damage by free radicals initiates the activation of the immune system, such as Kupffer cells, which stimulate the infiltration of inflammatory cells from the plasma to the damaged tissue [21]. 


\section{CONCLUSION}

In this study, we demonstrated that $B$. javanica has potential hepatoprotective effects, with the strongest protection occurring at a $4 \mathrm{~g} / \mathrm{kg}$ mouse weight dosage. Hepatoprotection was observed in the form of decreased AST, ALT, and ALP activity and relevant changes in liver histopathology. Furthermore, this decrease likely occurred as a result of increased GSH synthesis, which is elicited by amino acids present in B. javanica. A decrease in damaged hepatocyte size and the number and amount of neutrophil infiltration in the central vein were seen histologically with BJM treatment. It shows neutrophil infiltration as a result of damage to the hepatocyte cell membrane.

\section{CONFLICTS OF INTEREST}

None declared.

\section{REFERENCES}

1. Tappi ES, Lintong P, Loho LL. Histopathological features of rat liver of wistar given tomato juice (Solanum lycopersicum) post-wistar induced liver injury of carbon tetrachloride (CCl4). J Biomed 2013;1:1126-9.

2. Ali M, Qadir MI, Saleem M, Janbaz KH, Gul H, Hussain L, et al. Hepatoprotective potential of convolvulus arvensis against paracetamolinduced hepatotoxicity. Bangladesh J Pharmacol 2013;8:300-4.

3. Zhang ZF, Liu Y, Lu LY, Luo P. Hepatoprotective activity of Gentiana veitchiorum Hemsl. Against carbon tetrachloride-induced hepatotoxicity in mice. Chin J Nat Med 2014;12:488-94.

4. Dineshkumar G, Rajakumar R, Mani P, Johnbastin TM. Hepatoprotective activity of leaves extract of eichhornia crassipes against CCL4 induced hepatotoxicity albino rats. Int J Pure Appl Zool 2013;1:209-12.

5. Ristiyanti M. Marwoto, RM, Isnaningsih NR. Study on the freshwater mollusc diversity of the small lakes along Ciliwung and Cisadane rivers. Berita Biol 2014;13:181-9.

6. Urrego LE, Correa-Metrio A, González C, Castaño AR, Yokoyama Y. Contrasting responses of two Caribbean mangroves to sea-level rise in the Guajira Peninsula (Colombian Caribbean). Palaeogeogr Palaeoclimatol Palaeoecol 2013;370:92-102.

7. Gomes A, Alam MA, Datta P, Bhattacharya S, Gomes A. Hepatoprotective activity of the edible snail (Bellamia bengalensis) flesh extract in carbon tetrachloride induced hepatotoxicity in rats.
J Ethnopharmacol 2011;138:228-32

8. Chakraborty D, Mukherjee M, Maity J. Ethno-medicinal importance of viviparous gastropod, Bellamya bengalensis (Lamarck, 1822) in terms of estimation of its proximate protein and amino acid composition. Int J Recent Sci Res 2015;4:178-80.

9. Wu G, Fang YZ, Yang S, Lupton JR, Turner ND. Glutathione metabolism and its implications for health. J Nutr 2004;134:489-92.

10. Auliah A. The effect of age on the diversity of amino acid content of earthworms Lumbricuss rubellus. J Chem 2008;9:37-42.

11. Ranawat L, Bhatt J, Patel J. Hepatoprotective activity of ethanolic extracts of bark of Zanthoxylum armatum $\mathrm{DC}$ in $\mathrm{CCl}_{4}$ induced hepatic damage in rats. J Ethnopharmacol 2010;127:777-80.

12. Raj B, Singh SJ, Samual VJ, John S, Siddiqua A. Hepatoprotective and antioxidant activity of Cassytha filiformis against $\mathrm{CCl}_{4}$ induced hepatic damage in rats. J Pharm Res 2013;7:15-9.

13. Tiwari P, Ahirwae D, Chandy A, Ahirwar B. Evaluation of hepatoprotective activity of alcoholic and aqueous extracts of Selaginella lepidophylla. Asian Pac J Trop Dis 2014;4:S81-6.

14. Ramaiah S, Jaeschke H. Role of neutrophils in the pathogenesis of acute inflammatory liver injury. Toxicol Pathol 2007;35:757-66.

15. Dixit N, Baboota S, Kohli K, Ahmad S, Ali J. Silymarin: A review of pharmacological aspects and bioavailability enhancement approaches. Indian J Pharm 2007;39:172-9.

16. Robert SM, James RC, Franklin MR. Hepatotoxicity: Toxic effect on the liver. In: Williams PL, James RC, Roberts AM, editors. Principles of Toxicology. New York: John Wiley and Sons; 2000. p. 111-27.

17. Lu CF, Kacew S. Lu's Basic Toxicology: Fundamentals, Target Organs and Risk Assessment. $4^{\text {th }}$ ed. London: Taylor and Francais; 2002.

18. Lu M, El-Shazly M, Wu T, Du Y, Chang T, Chen C, et al. Recent research and development of Antrodia cinnamomea. Pharmacol Ther 2013;139:124-56.

19. Pavarino EC, Russo A, Galbiatti AL, Almeida WP, Bertollo EM. Glutathione: Biosynthesis and mechanism of action. In: Labrou N, Flemetakis E, editors. Glutathione: Biochemistry, Mechanisms of Action and Biotechnological Implications. New York: Nova Science Publishers; 2013. p. 6-20.

20. Townsend DM, Tew KD, Tapiero H. The importance of glutathione in human disease. Biomed Pharmacother 2013;57:145-55.

21. Reza HM, Sagor MA, Alam MA. Iron deposition causes oxidative stress, inflammation, and fibrosis in carbon tetrachloride-induced liver dysfunction in rats. Bangladesh J Pharmacol 2015;10:152-9. 